\title{
Istanbul 2007
}

\author{
By Gönül Dönmez-Colin
}

Fall 2007 Issue of KINEMA

\section{ISTANBUL INTERNATIONAL FILM FESTIVAL}

Istanbul International Film Festival (31 March-15 April 2007) celebrated its $26^{\text {th }}$ birthday this spring with more than 200 films from around the world.

This year, for the first time in its history, the festival opened with a film by a Turkish director, Ferzan Özpetek although the Italian production Saturn Opposite about depressed 40-year olds nostalgic about their youth, featuring some of the well-known actors of Italy could hardly be considered a Turkish film. The closing film was the US production, The Good German by Steven Soderbergh featuring George Clooney and Cate Blanchett.

The films that compete for the Golden Tulip award are chosen for their relation to art and the artist or are adaptations from literary works. The fact that Istanbul takes place shortly before Cannes makes it rather difficult to find quality films for the International Competition, which had not been previously screened elsewhere. Nevertheless, among the fifteen competing films, there were some interesting ones such as Tom DiCillo's latest film Delirious, Bahman Ghobadi's Niweman (Halfmoon) and the French Lady Chatterley directed by Pascale Ferran. The two Turkish entries, Beynelmilel (International) by Srr Süreyya Önder and Muharrem Gülmez and Cenneti Beklerken (Waiting for Heaven) by Dervi Zaim, respectively, a contemporary political satire and an allegorical period piece, were testimony to the diversity in New Turkish cinema.

Set during the darkest days of the 1980 coup d'état, which has left deep scars on the modern Turkish psyche, International starts as a comedy and a romantic love story, which ends with unexpected political violence, not unlike the lives of ordinary apolitical citizens who often take shelter under false security to be awakened one day with the stark reality. Waiting for Heaven is a parable set in the $17^{\text {th }}$ century and shot in the style of a road movie. The film uses the past to understand the present and the question of identity for Turkish society extrapolating the dichotomy of the Eastern art versus the Western.

Among the films in the National Competition Mutluluk (Bliss) by Abdullah Ouz drew attention for its plastic qualities, its subject matter of honor killing (adapted from a novel by Zülfü Livanelli) and the exceptional acting of the young duo, particularly Özgü Namal, the shining star of Turkish cinema, whose performance in International was also remarkable. klimler (Climates) by Nuri Bilge Ceylan, shot in HD-digital video and acted by himself and his wife Ebru Ceylan, was shot in Ceylan's usual self-reflexive style. Zeki Demirkubuz, on the other hand, returned to his second film, Masumiyet (Innocence) and created a past for his characters in Kader (Destiny) exploring love, passion and obsession in his usual melodramatic style.

Director of films such as Gemide (On Board, 1998), which had had critical acclaim, Serdar Akar received the ire of many when he directed the ultra-nationalistic and violent film Kurtlar Vadisi Irak (Valley of the Wolves Iraq, 2005) and its TV versions. His latest film, Barda (At the Bar) was a commentary about the social and economical inequality in Turkish society, which sent its message across through graphic violence. Takva (Takva-A Man's Fear of God) by Özkan Kzltan, on the other hand focused on the Islamic orders, which were banned by Atatürk but resurfaced in a menacing way in the last few years. Already acclaimed at several international film festivals, Takva excelled with its sound script, skillful direction and the performance of the actors.

One could easily say that it was a good year for Turkish cinema. Two veterans joined the ranks. One in competition and one out of competition. Zeki Ökten who had collaborated with Ylmaz Güney and directed Düman (Enemy) and Sürü (The Herd) for him, made a come back with Cinliler Geliyor (The Chinese Are Coming), a satire on globalization and Engin Ayça, whose last fiction film (his second) was made in 1991, presented Suna, a nostalgic story of the '68 generation and the 1970 coup d'état, starring the sultana of Turkish cinema, Türkan oray. 
A notable factor was the number of national films that focused on the scars of the military take-overs. In addition to International and Suna, Zincirbozan by Atil naç, Küçük Kyamet (Little Apocalypse) by Yamur and Durul Taylan, Eve Dönü (Homecoming) by Ömer Uur (starring Sibel Kekilli of Head On fame) and Fikret Bey by Sema Köksal also dealt with such dark corners of recent history. This could perhaps be attributed to the relaxation of the restrictions in recent years. It is a good sign that Turkish cinema has begun to find a way to deal with the past although there is no film yet which attacks the subject 'head on.' Often crucial elements are missing, which makes it difficult for those unfamiliar with recent unofficial history (not only foreigners but also the young generation of Turks) to comprehend what happened.

In addition to the fiction film, Bliss, which focused on the custom of honour killings, which is still practice today, a timely documentary called Kadna At (Requiem for Women) by Berrin Balay and Önder M. Özdem exposed such violence committed against women in the name of customs.

In the Human Rights in Cinema section, Indigènes (Days of Glory) by Rachid Bouchareb focused on the unnamed soldiers of the French army, the North Africans who fought the World War II for the French, only to be refused their pension in 1959. Flandres (Flanders) by Bruno Dumont and Bamako (The Court) by Abderrahmane Sissako were some of the other noteworthy films in this section.

In the From the World Festivals section, some of the eye-catching films were Japanese Hirokazu Kore-Eda's Hana Yori Mo Naho (Hana, 2006), Yihe Yuan (Summer Palace) by Lou Ye (China), Indian Mira Nair's United States production, The Namesake (based on the acclaimed novel by Jhumpa Lahiri), Sang Sattawat (Syndromes and a Century) by Apichatpong Weerasethakul (Thailand) and Sa Xia Haoren (Still Life) by Jia Zhangke (China).

The In Memoriam section honoured the masters that have passed away: Atf Ylmaz, Robert Altman, Shoei Imamura, Sven Nykvist and Gillo Pontecorvo. Gus Van Sant, Fassbinder, Pasolini and Bob Fosse were also honoured with selections from their works.

\section{References}

\section{AWARDS}

International Competition

The Golden Tulip Award: Reprise by Joachim Trier (Norway)The Special Prize of the Jury: Delirious by Tom Dicillo (USA)

National Competition

Best Turkish Film of the Year: klmler (Climates) by Nuri Bilge Ceylan

Best Director of the Year: Zek Demrkubuz for his film Kader (Destiny)

Best Actress Özgü Namal for her performance in Beynelmilel (International)

Best Actor shared between Erkan Can for his performance in Takva (Takva: A Man's Fear of God) and Ufuk Bayraktar for his performance in Kader (Destiny)

The Special Prize of the Jury Beynelmlel (International) by Srr Süreyya Önder \& Muharrem Gülmez

Face Award (The Film Award of the Council of Europe) given to a film from the Human Rights in Cinema section, Bamako (The Court) by Abderrahmane Sissako (Mali)

\section{FIPRESCI Awards}

The FIPRESCI Award in the International Competition to Kunsten at Graede I Kor (The Art of Crying) by Peter Schønau Fog (Denmark)

The FIPRESCI Award in the National Competition

Kader (Destiny) by Zeki Demirkubuz

\section{People's Choice Awards}

Niwemang (Half Moon) by Bahman Ghobadi (Iran) in the International Competition, and klmler (Climates) by Nuri Bilge Ceylan in the National Competition. 


\section{Author Information}

Gönül DÖNMEZ-COLIN is an independent researcher and writer whose publications include Women, Islam and Cinema, Cinemas of the Other: A personal Journey with Filmmakers from the Middle East and Central Asia, Cinema of North Africa and the Middle East (ed.); Turkish Cinema: Identity, Distance and Belonging (Reaktion Books), and Routledge Dictionary of Turkish Cinema (2014). 